УДК 81:39(497.11)(495)

https://doi.org/10.18485/msc50_vuk_trsic.2021.ch5

Јанис Какридис

\title{
ЈЕЗИЧКА РЕФОРМА КАО СИНТЕЗА НОРМАТИВНОГ И ДЕСКРИПТИВНОГ ПРИСТУПА: ВУК КАРАЏИТ И ЈАНИС ПСИХАРИС
}

Дело Вука Караџића се често упоређује са делом Адамантиоса Кораиса. Међутим, оно има више заједничких тачака са делом Јаниса Психариса (1854-1929), са чијим именом је повезан револуционарни преокрет у историји новогрчког кюижевног језика. Као што је Караиић настојао на посбртивану рускословенске тексике, исто тако је Психарис захтевао да „горни слој” лексике буде доследно прилагођаван фонетским и морфолошким законима новогрчког језика. У оба случаја, то настојане има своју идеолошку подлогу у језичком национализму, који у стандардном језику тражи узорак синтезе између субјективног и објективног начела историјског развитка.

Кључне речи: Вук Караџић, Јанис Психарис, језички национализам, стандардизација, дескриптиван приступ, нормативан приступ, гласовни закони.

На питање о односу нормативног и дескриптивног приступа у процесу стандардизације може се дати веома једноставан, практичан одговор: стандардни језик мора да буде дескриптиван колико може и нормативан колико треба. Међутим, као што је добро познато, питање стандардног језика има не само практичну, него и идеолошку димензију. Од деветнаестог века до данас оно је повезано са питањем националног идентитета: „кад стварамо нову граматику”, писао је 1913. године професор Атинског универзитета Георгиос Мистриотис, „стварамо нову на-

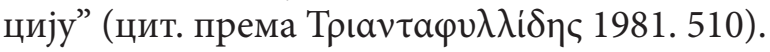

У једном класичном есеју из 1926. године, Carlton J. H. Hayes је описао национализам као врсту религије. Национални покрети имају своје

${ }^{1}$ Задржавамо усмену форму излагања, додајући само најважније библиографске податке. Српског читаоца заинтересованог за питања језичког национализма упућујемо на радове Р. Бугарскога $(2001,2002)$. 
симболе, своје ритуале, своје мученике и свеце, чак и своје реликвије. ${ }^{2}$ Можемо ићи један корак даље: национализам (мислимо пре свега на романтички национализам) је религија у смислу Хегелове дефиниције према којој се у религиозном мишљењу природа и слобода, објективно и субјективно начело поистовећују. ${ }^{3}$ Теоретичари национализма већ много година воде дискусију о питању да ли су нације историјске датости или идеолошке конструкције, те су дошли до закључка да важи и једно, и друго (Hroch 1998). То је доста тривијално, јер свака историјска појава садржи поред нових елемената и елементе који су наслеђени из прошлости. Тврдња да је нација истовремено историјска датост и политички пројекат, прошлост и будућност, индикатив и императив историје, добија свој прави значај тек кад додамо да се за припаднике националног покрета та два момента претапају у неком дубљем јединству, у свеобухватној тоталности која се може дефинисати само таутолошки (Какридис 2002).

Религиозна природа романтичког национализма одређује и његов став према језику. По својој дијалектичкој природи, језик пружа идеално поље за остварење националистичке синтезе субјективног и објективног начела историјског процеса. Ту лежи дубљи разлог језичког национализма, у коме не треба тражити нити механички одјек Хердерових идеја нити неку тајанствену особину словенских народа. У националистичком контексту, процес језичке стандардизације нема чисто практичну сврху. Књижевни језик служи не само модернизацији нације него постаје симбол њене аутентичности. Појмови стандардног језика и националног језика се поистовећују. Граматичари и лексикографи су позвани да остваре синтезу у којој разлика између објективног, тј. дескриптивног, и субјективног, тј. нормативног начела језичког развитка нестаје. Они своју властиту, нормативну улогу морају одиграти на такав начин да би она постала невидљива за њихове савременике, чак и за њих саме.

Илустроваћу то Караџићевим ставом према позајмицама из рускословенског и руског језика, које су у његово доба превладавале у

${ }^{2}$ Hayes 1966, уп. Durkheim 1960. 610: „Quelle différence essentielle y a-t-il entre une assemblée de chrétiens célébrant les principales dates de la vie du Christ, ou de juifs fêtant soit la sortie d'Égypte soit la promulgation du décalogue, et une réunion de citoyens commémorant l'institution d'une nouvelle charte morale ou quelque grand événement de la vie nationale?"

${ }^{3}$ „Wo Subjekt und Objekt oder Freiheit und Natur so vereinigt gedacht wird, dass Natur Freiheit ist, dass Subjekt und Objekt nicht zu trennen sind, da ist Göttliches ein solches Ideal ist das Objekt jeder Religion. Eine Gottheit ist Subjekt und Objekt zugleich, man [kann] nicht von ihr sagen, dass sie Subjekt sei im Gegensatz gegen Objekte oder dass sie Objekte habe" (Hegel 1986. 242). 
„горњем слоју” лексике књижевног језика, тј. у апстрактној и цивилизацијској лексици. По мишљењу П. Ивића, ове речи се нису увек добро уклапале у структуру српског језика, „али се језичко осећање на њих већ било навикло толико да је најчешће само учени филолог могао познати да су оне дошле са стране" (Ивић 1998: 199). Као што је познато, Караџић је настојао да те позајмице или уопште избаци из српског књижевног језика или да их барем прилагоди његовом гласовном и творбеном систе-

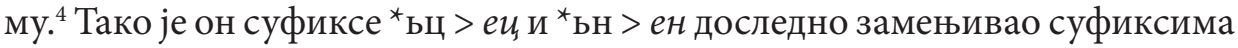
аи, и ан: богобораи, среброљубаи, ... јединодушан, сујетан; о црквенословенској форми суфикса * $ь$ (е) > ије рекао да је она „најнеобичније у свему Српском језику" (Караџић 1894: 2, 139 = Караџић 1968-2001: II, 69), па су под његовим пером братолюбіе, человеколюбіе, искушенїе, обрзаніе постали братольубеем, човекольблем, искушенем, обрезатем, а гостолюбїе - гостолубивост. Человческї није му изгледало „довољно посрбљено кад се начини човеческї: зашто Србљин каже човечији" (Караџић 1894: 2, 110 = Караџић 1968-2001: II, 58), пророчество је постало пророчтво, отечество је постало отачанство итд. Вуков пуризам распростирао се чак на речи које са синхронијског гледишта нису нарушавале законе српског језика, као на пример тубезан, жертва или кюаз. ${ }^{5}$ То се већ не да објаснити само практичним разлозима. Прави узрок ових замена је свесна или несвесна чежња за идеолошким знаком који би оличио синтезу нормативног и дескриптивног начела, модернизације и аутентичности. Рускословенска реч и после посрбљавања остаје нешто што је дошло у српски језик са стране, али својим обликом ствара илузију да припада његовом изворном лексичком фонду. То је нормативност у облику дескриптивности, модернизација у облику аутентичности. Наравно, на тај начин се постиже привидно јединство које обухвата само формалну, а не и семантичку страну језика. Чак и са формалног гледишта српски књижевни језик не може бити потпуно јединствен јер се српска књижевна традиција већ пре Караџића обогатила (са пуристичког гледишта: контаминирала) старословенским позајмицама попут општи или праведан.

У грчком случају, идеолошки фактор фонолошког и морфолошког прилагођивања „горњег слоја” књижевног језика постаје још упадљи-

4 „Ми истина можемо Рчи, кое немамо у обштему говору, узимати из Славенскога язика; али такове рчи треба по Серблявати што се више може, да не стое из медьу прості́ Сербскі́ рчи као янад из медьу оваца” (Караџић 1968-2001: $\mathrm{I}, 17)$.

${ }^{5}$ О србизирању рускословенских термина код Вука и о његовом ставу према славеносрпском језику в. Ивић 1991: 226-248, Младеновић 1989: 62-64 и 146159, Толстој 1988: 194-201. 
вији. Ја ћу то показати на примеру Јаниса Психариса. У славистици постоји већ дуга традиција да се Караџићево дело упоређује са делом Адамантиоса Кораиса. ${ }^{6}$ У типолошком погледу, међутим, Кораису је ближи Доситеј Обрадовић са својим хибридним језиком и просветитељским утилитаризмом него Вук Караџић. ${ }^{7}$ Револуционарни преокрет према народном језику који је у историји српског књижевног језика везан за име Караџића у историји грчког књижевног језика покушао је да оствари мада с далеко мањим успехом - Јанис Психарис. ${ }^{8}$

Психарис се родио 1854. г. у Одеси, у породици трговаца која је водила своје порекло са грчког отока Хиоса. Рано је изгубио мајку па је одрастао код баке, најпре у Цариграду, касније у Марсеју и Паризу, где је завршио гимназију. Од 1874. г. студира класичну и романску филологију у Паризу. Дипломира 1879, а неколико година касније, 1885, постаје maître de conférences за новогрчку филологију и језик на École des hautes études (Kрıарás 1981, Крıарác 2007). Летом 1886. г. Психарис путује као изасланик француског министарства просвете у Цариград, Хиос и Атину. Плод тог путовања је дело по којем је одмах постао познат и по којем

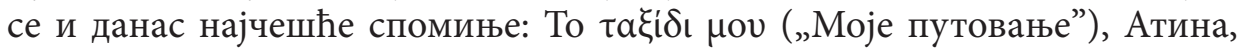

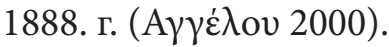

То $\tau \alpha \xi i \delta \iota \mu v$ није путопис у класичном смислу те речи. Путовање је за аутора само схема за организацију разноврсних рефлексија о историјској судбини и савременом стању грчког народа. Централно место у тим рефлексијама заузима питање књижевног језика. Психарис се бори против архаизираног књижевног језика његових савременика (каӨ $а \rho \varepsilon v \dot{v v \sigma \alpha) ~ и ~ з а л а ж е ~ с е ~ з а ~ к њ и ж е в н и ~ ј е з и к ~ н а ~ н а р о д н о ј ~ о с н о в и . ~ У ~}$ ствари, његов својеврсни путопис је прво опширно прозно дело новогрчке литературе, које је написано искључиво тзв. народним језиком

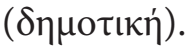

Нема потребе да се заустављамо на биографији Психариса, који је и даље наставио борбу за решење језичког питања (за „Идеју”, како је сам говорио). Да споменемо само да је био зет познатог историчара Ернеста Ренана (оженио се његовом ћерком Ноеми 1882. г.), и да је 1904. г. наследио неогрецисту Емила Леграна на катедри за новогрчки језик у École des langues orientales vivantes. Писао је научна и литерарна дела, и

${ }^{6}$ Hopf 1997, уп. примедбу Копитара да и Србима треба „Xerkules-Korais”, Kopitar 1857. 262.

7 За преглед основних разлика између језичких програма Доситеја и Караџића, в. Поповић 1996.

${ }^{8}$ Психарис је имао низ претходника, од којих, као што је приметила К. Хопф (Hopf 1997: 152), с Караџићем се може нарочито упоредити Иоанис Виларас. 
то на оба језика: на новогрчком и на француском. Његова прва књига на подручју грчке филологије (Essais de grammaire historique néo-grecque, 1. том, Париз 1885) изазвала је оправдану критику Георгиоса Хаџидакиса, професора лингвистике на Атинском универзитету. Са Хаџидакисом је Психарис био у сукобу све до краја свог живота (умро је 1929. г.). Хаџидакис га је називао „јересиархом”, а Психарис је укључио у своју велику

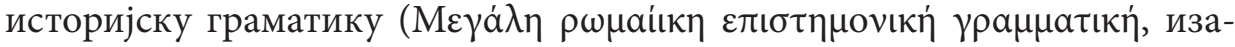
шла посмртно у три тома 1929, 1935. и 1939. године) многобројне личне

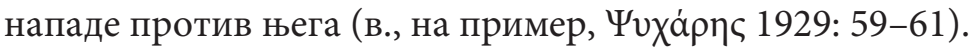

Паралеле између Караџића и Психариса упадају у очи. Обојица су се борили за језик народа - „пастира и орача” (Караџић 1894, 1, 159),

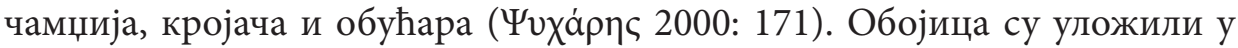
ту борбу сву снагу једног изразито полемичког темперамента. ${ }^{9}$ Обојица су имали базу изван своје домовине и покровитељство водећих представника светске науке свог времена. Све те паралеле, наравно, сведоче пре свега о томе да Караџић и Психарис заузимају типолошки слична места у историји српског односно новогрчког књижевног језика, а не о неком дубљем Вуковом утицају на Психариса. Психарис вероватно никад није проучавао дела свог претходника, мада је познавао његово име. Он спомиње Караџића у једном од својих раних радова да би истакао заосталост новогрчке филологије: Грци се једва могу надати да ће након стотину година добити свог Дица, свог Бопа, свог Грима или барем свог Вука Караџића. ${ }^{10}$ Караџић се ту додаје готово презриво да би се показало колико су Грци заостали иза других европских народа: чак и свог Караџића они ће морати да чекају још прилично дуго.

Психарис, који је био човек готово патолошке амбиције, сигурно је мислио да ће он сам постати грчки Диц, Боп, Грим или барем грчки Караџић. По галами коју је дигао у грчкој литератури могло би се рећи да је у томе и успео. Што се тиче решења конкретних питања језичке стандардизације, међутим, његови предлози нису имали исти успех. Постоје најмање два разлога за то. Први је чињеница да је углед књижевне традиције у грчком случају био неупоредиво виши него у српском, а број писмених људи вероватно већи. С тим у вези мора се споменути и главна разлика између Караџића и Психариса: и поред све своје борбености, Психарис

${ }^{9}$ „Les fous, ceux atteints de folie furieuse, dont je suis évidemment, ont le tempéramment combatif”, писао је о себи Психарис (Psichari 1930: 1267).

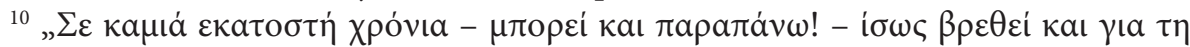

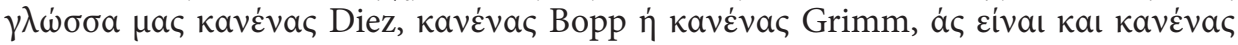

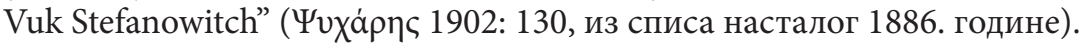


се никад није усудио да проведе ортографску реформу, мада је јасно схва-

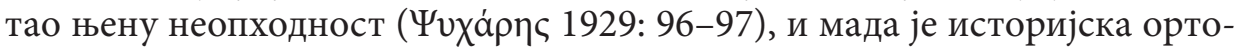
графија главни узрок те илузије против које се борио целог свог живота: да је грчки језик од античких времена до данас остао без промена. Други разлог за Психарисов неуспех је недостатак тог непогрешивог осећања за матерњи језик којим је располагао Вук Караџић. Психарисов први језик је био руски, са својим рођацима (осим баке) говорио је француски, а грчки је научио тек од слуга (Psichari 1930: 1262-1263; Kрıара́с 2007: 267). У ствари, Психарис је одрастао управо у тој трговачкој, космополитској, градској средини која је по мишљењу Караџића одговорна за кварење матерњег језика код Срба.

Какав је био став Психариса према апстрактној и цивилизацијској лексици? Психарис је мислио да народни језик треба обогатити пре свега народним средствима, па се није устручавао од неологизама. Њего-

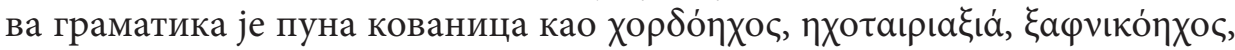

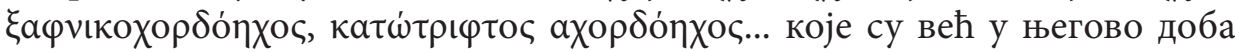
изазивале подсмех. ${ }^{11}$ Психарис, међутим, није одбацивао ни позајмице из претходних периода развитка грчког језика, поготову ако су се оне већ биле укорениле у језичкој свести говорника. Исто тако као Караџић, настојао је да ове позајмице буду прилагођене фонолошким и морфолошким законима савременог језика. Тај став је Психарис доследно бра-

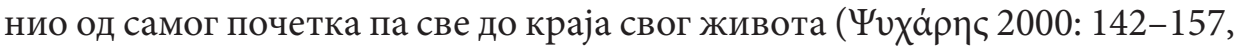

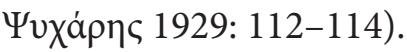

Ево неколико примера. Новогрчки језик не познаје комбинацију назал + фрикатив. Психарис, дакле, препоручује да се пише и изгова-

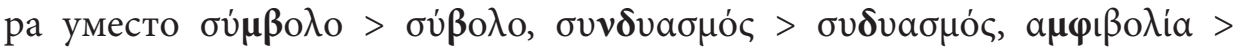

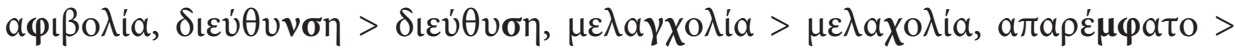

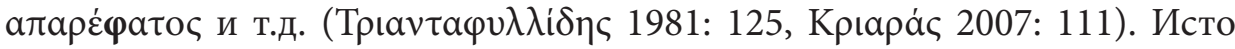
тако /пт/, /кт/ је у историји грчког језика прешло у /фт/, /хт/, па Психа-

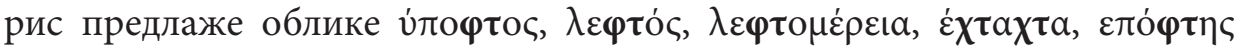

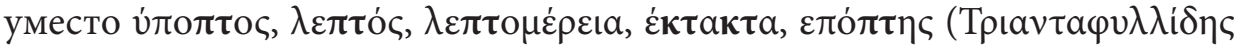

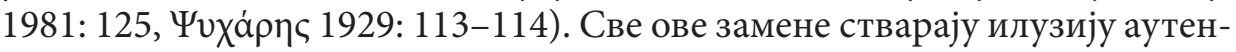
тичности која служи не само идеолошким, него и практичним сврхама.

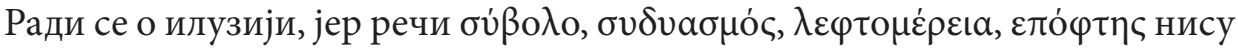
преживеле у устима народа, већ су учене позајмице и остаће такве не-

${ }^{11}$ Уп. с тим опрезан приступ Караџића питању србизације црквенословенске граматичке терминологије (Младеновић 1989: 69-70). 
зависно од начина на који се пишу и изговарају. ${ }^{12}$ Да ова илузија служи не само практичним, него и идеолошким сврхама, види се по томе што се Психарисове замене (као неке Караџићеве) распростиру на речи које не нарушавају живе, него само историјске законе фонолошког развит-

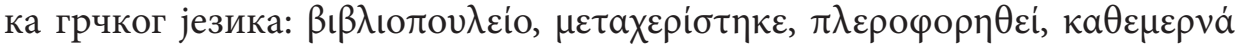

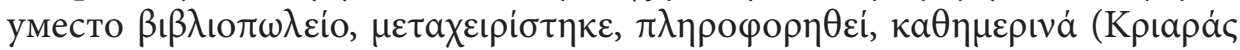
2007: 154, 301, 318). Ту се очигледно не ради о олакшању изговора него само о активацији етимолошке свести која у неким случајевима не одго-

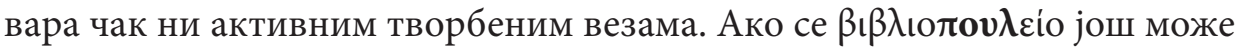

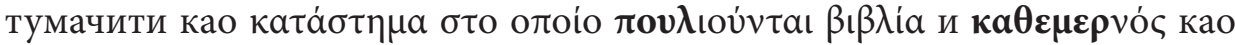

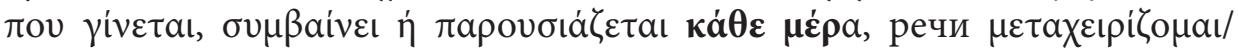

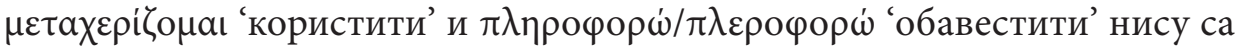

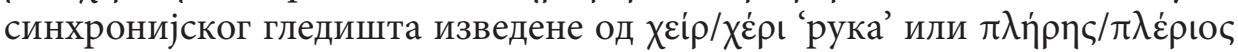
'потпун'. Следећи нараштај присталица језичке реформе с пуним правом је одбацио Психарисов приступ питању апстрактне и цивилизацијске лексике. ${ }^{13}$

Као што су већ многи истраживачи забележили, доследност (да не кажемо фанатизам) Психариса у питању фонолошке адаптације позајмица има своју (псеудо)научну основу у младограматичарској тези да се гласовне промене врше по законима који не познају изузетке. ${ }^{14}$ Код младограматичара, наравно, гласовни закони имају строго дескриптиван статус: говорници их примењују несвесно а не због неке моралне обавезе. Код Психариса гласовни закони добијају нормативан статус, они постају оруђе и мерило стандардизације. Нема бољег доказа за идеолошку (у смислу Хегелове дефиниције: религијску) основу језичке стандардизације националистичког доба од ове метаморфозе природног закона у морални закон, дескриптивног начела у нормативно начело.

${ }^{12}$ Код неких од њих то се види већ по форми: по законима гласовног развитка

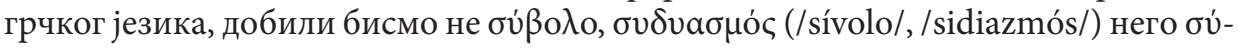

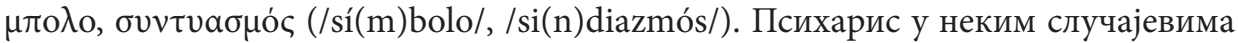

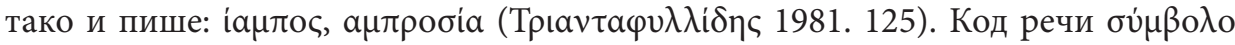

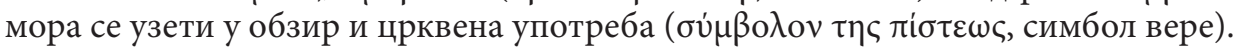

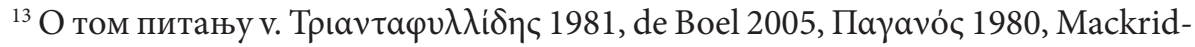

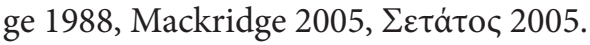

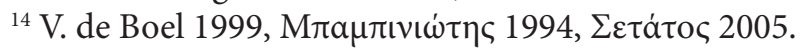


Бугарски, Ранко 2001: Лииа језика. Социолингвистичке теме. Београд: Библиотека XX век.

Бугарски, Ранко 2002: Нова тица језика. Социолингвистичке теме. Београд: Библиотека XX век.

Ивић, П. 1991: О Вуку Карачићу, Приредио Александар Младеновић. (Целокупна дела IV), Сремски Карловци, Нови Сад: Издавачка књижарница Зорана Стојановића.

Ивић, П. 1998: Преглед историје српског језика, Приредио Александар Младеновић, (Целокупна дела VIII). Сремски Карловци, Нови Сад: Издавачка књижарница Зорана Стојановића.

Караџић, Вук 1894: Скупљени граматички и полемички списи, Књига прва. Београд.

Караџић, Вук 1968-2001: О језику и књижевности, Књиге I - III, 1, (Cабрана дела 12-14,1). Београд: Просвета.

Младеновић, А. 1989: Славеносрпски језик, Студије и чланци, Нови Сад: Књижевна заједница Новог Сада.

Толстој, Н. И. 1988: История и структура славянских литературных языков, Москва: Наука.

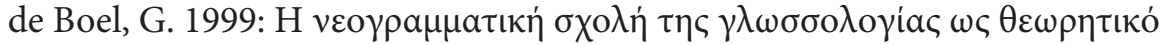

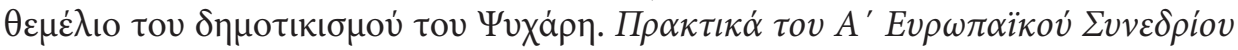

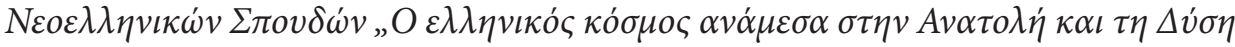

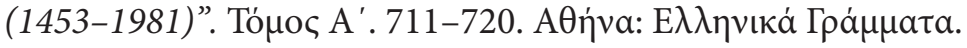

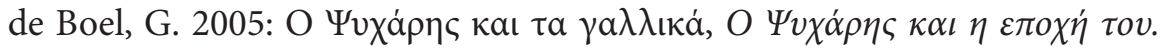

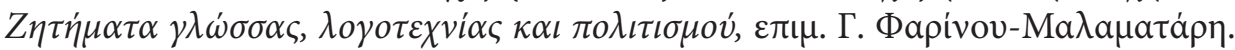

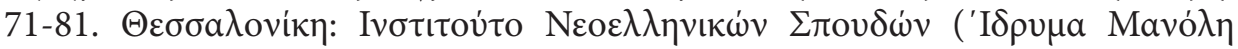

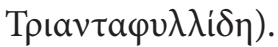

Durkheim, É. 1960: Les formes élémentaires de la vie religieuse. Le système totémique en Australie, 4e édition. (1ère édition 1912). Paris : Quadrige / PUF.

Hayes, Carlton J. H. 1966: Nationalism as Religion. In: Essays on nationalism. 93-125. Neš York: Russel \& Russel (1st edition 1926).

Hegel, Georg Wilhelm Friedrich 1986: Frühe Schriften. (Werke 1). Frankfurt a.M.: Suhrkamp.

Hopf, C. 1997: Sprachnationalismus in Serbien und Griechenland. Theoretische Grundlagen sošie ein Vergleich von Vuk Stefanović Karadžić und Adamantios Korais, - Wiesbaden: Harrassošitz. 
Hroch, M. 1998: Real and constructed: the nature of the nation. In: Hall, John A. (ed.). The State of the Nation. Ernest Gellner and the Theory of Nationalism, 91-106. Cambridge.

Kakridis, Y.: The Role of Tautologies in Nationalist Discourse (Preliminary Remarks), Nacionalni identitet i suverenitet u jugoistočnoj Evropi. Medunarodni naučni skup 8.-10. decembar 1999. 313-322. Beograd 2002.

Kopitar, B. 1857: Barth. Kopitars kleinere Schriften sprachšissenschaftlichen, geschichtlichen, ethnographischen und rechtshistorischen Inhalts, Herausgegeben von Fr. Miklosich. Wien.

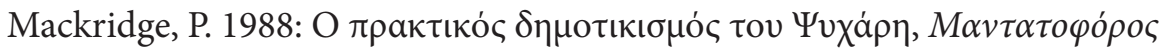
28. 40-45.

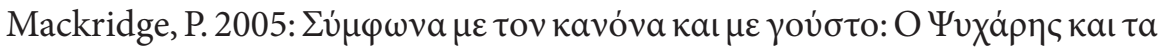
ó

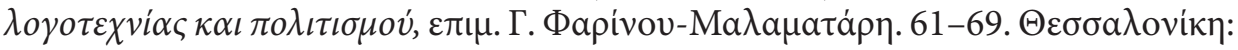

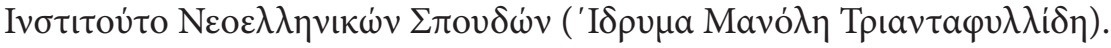

Popović, Ljubomir 1996: Deux approches idéologiques de la vernacularisation de la langue littéraire chez les Serbes à la fin du $18^{\text {ème }}$ et dans la première moitié du $19^{\text {ème }}$ siècle, Langue et nation en Europe centrale et orientale du XVIIIème siècle à nos jours. Ed. par Patrick Sériot (Cahiers de l'ILSL № 8). 209-240. Lausanne.

Psichari, J. 1930: Quelques travaux de linguistique, de philologie et de littérature helléniques, 1884-1928. 2 Tomes. Paris: Les Belles Lettres.

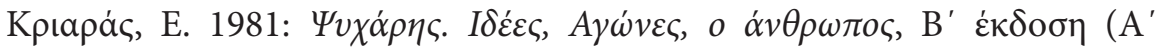

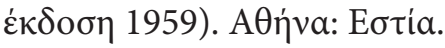

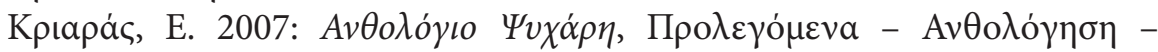

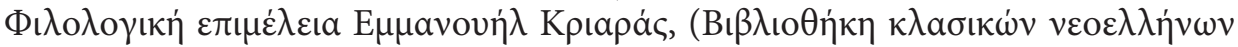

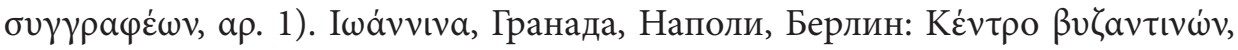

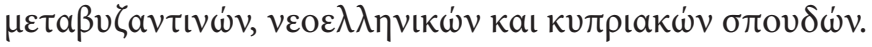

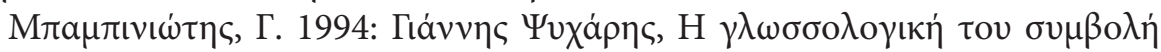

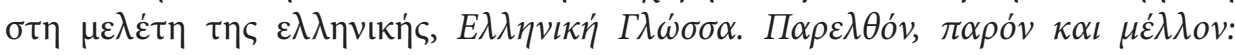

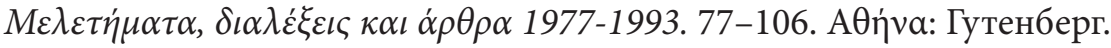

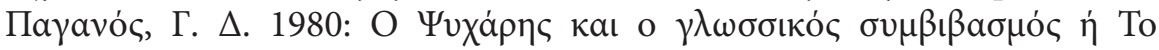

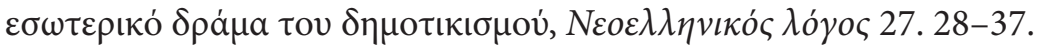

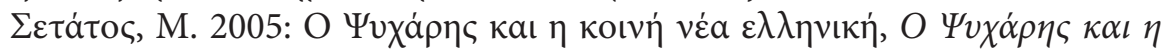

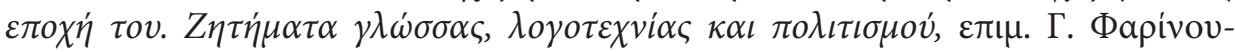

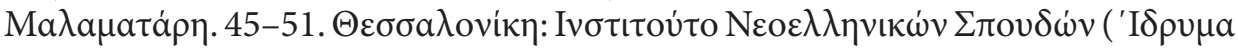

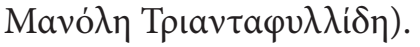

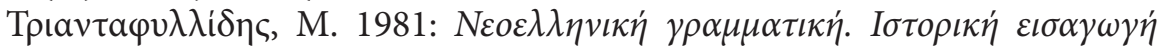

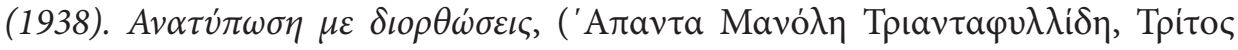

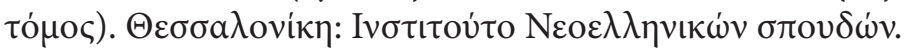




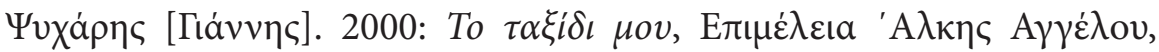

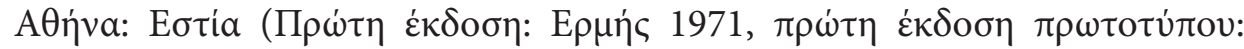
A $\theta$ ńva 1888).

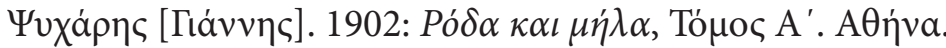

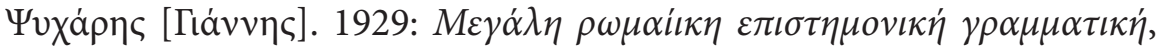

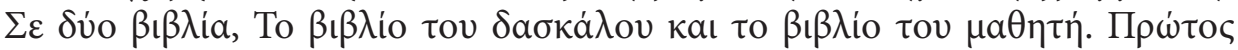

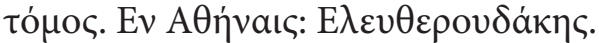

* Рад је претходно објављен у зборнику Научни састанак слависта у Вукове дане, 37/1, 351-359. 